\title{
Fuzzy Ownership: A Theory of Corporate Governance and Evidence from Korea*
}

\author{
EUGENE YUN ${ }^{* * *}$ AND BLISS BURDETT PAK ${ }^{* * *}$
}

\begin{abstract}
This paper presents a model with "fuzzy ownership rights" for explaining corporate governance. The purpose of this model is to capture the theoretical underpinnings of corporate governance in real-world situations, which emphasize social, economic and cultural networks. The existence of strong fuzzy ownership rights affects corporate governance in many important ways, beginning with the firm being forced to go beyond solving the shareholder interest maximization problem: instead, the firm attempts to solve a more complex problem, which is to maximize the interests of other fuzzy ownership right-holders as well.

In the wake of the Asian financial crisis in 1997, many countries in Asia were encouraged to adopt western-style corporate governance reforms. Although systemic changes are being adopted, with particular emphasis placed on strengthening minority shareholders' legal rights, these reforms fail to remove fuzzy ownership rights. This paper predicts that the reform effort will be ineffectual since it leaves the behavior of the firm and its corporate governance structure fundamentally unchanged.

This paper challenges the proposition that globally disparate corporate governance systems in the long run will converge to the Anglo-Saxon shareholder primacy model. Fuzzy ownership rights holders can be expected to protect and refuse to surrender their rights when targeted by corporate reform efforts. The vested interests, which are personal to the holders because they arise from the holder's position in the economy or in relation to the firm, present a high barrier to convergence toward a global standard based on the shareholder primacy model.
\end{abstract}

Keywords: corporate governance, convergence, shareholder primacy, agency problem, controlling shareholder, shareholder rights, corporate ownership, stakeholder

\footnotetext{
This paper was originally presented at a conference of the Asia-Europe Perspective Association, Seoul, on November 18, 2005.

First Author, Eugene Yun, Assistant Professor, Graduate School of International Studies, Ewha Womans University, 11-1 Daehyun-dong, Seodaemun-gu, Seoul, 120-750, South Korea; Tel: 82-11-395-3785; E-mail: eugyun@ewha.ac.kr

Bliss Burdett Pak, Visiting Professor, Graduate School of International Studies, Ewha Womans University, 11-1 Daehyun-dong, Seodaemun-gu, Seoul, 120-750, South Korea; Tel: 82-2-3277-4691; E-mail: blisspak@ewha.ac.kr
} 


\section{INTRODUCTION}

7 he practice of corporate governance varies from place to place. This paper 1 presents a model with "fuzzy ownership rights" for explaining corporate governance as it is actually practiced in many parts of the world. Although key observations were taken from the Korean economy in developing the fuzzy ownership model, this paradigm captures the theoretical underpinnings of real-world corporate governance practice in any governance regime with comparable emphasis in social, economic and cultural networks.

In contrast to a shareholder-primacy model predictably advocated by minority and foreign investors, the fuzzy rights model explains the forces at work in corporate governance choices and may explain why legal rules imported or transplanted from different systems have little or no real effect on the behavior of domestic corporations. It should be stated at the beginning that the purpose of introducing this model is to direct the discussion on corporate governance issues in countries such as Korea closer to the factors that matter, and to provide better guidance for public policy-making. Moreover, this paper does not attempt to assert any normative statements as to whether the fuzzy ownership rights model is "better" or "worse" than the shareholder-primacy model.

Prior to the Asian financial crisis in 1997, the term "corporate governance" was hardly used in the region. In the aftermath of the financial crisis, corporate governance is the primary focus of a series of reforms in the affected economies. In Korea, for example, the reform program is designed to have wide reaching effects, including changing the chaebol, the financial markets and institutions, and the legal environment.

The idea that countries such as Korea should undergo a change in perception regarding the importance of corporate governance is quite understandable. The financial crisis revealed a serious flaw in Korea Inc. The massive failures at many key industrial groups and financial institutions were the result of an economic and political system incapable of withstanding sudden and unanticipated external shocks. In the crisis of 1997, the impetus came in the form of currency market volatility, whose shock propagated throughout the economy and destabilized the nation as a whole. ${ }^{1}$ In the wake of the financial crisis, investigators looking into its causes identified a long list of problems and weaknesses, including corporate governance.

To an outsider, the practice of corporate governance in Korea can be puzzling or bewildering. Indeed, many analysts argue that poor corporate governance was at the heart of the Korean financial crisis. Fraudulent misrepresentation of debt levels, embezzlement, the failure of banks (the major providers of capital to these companies) to assess credit risk, regulators routinely bought off with cash and other forms of bribes - these were revealed as common pre-financial crisis corporate practice. ${ }^{2}$ Against this backdrop, corporate governance debates 
took center stage as Korea and the global community attempted to identify and correct the key flaws.

Not coincidentally, there raged a heated discussion in the international community regarding the question of "good" corporate governance generally. 3 What constitutes best corporate governance practice? What models of corporate governance systems are found in market economies around the world? What exactly are the "corporate governance" - related problems that need to be addressed? Are they the same in different cultural and geographic settings? Is there a dominant corporate governance model? If so, will there be a convergence in varying corporate governance practice toward this global norm? What consequences for a national system that adheres to alternate structures?

The notion of global convergence is not unreasonable. At the same time, it is challenged by those who believe existing corporate governance arrangements will persist in non-conformist ways. Instead of a predicted homogenous set of corporate governance structures and practices, the future landscape may display significant diversity in corporate governance form and function globally. A case in point is Korea, which has been subjected to substantial legal reform in the wake of the financial crisis. Will the legal reform significantly impact actual practice at Korean companies?

In Section II, we examine the convergence theory for corporate governance, as well as some arguments for why convergence is unlikely to occur in Korea and other nations with cultural and institutional similarities. In Section III, we introduce the "fuzzy ownership" model of the corporation, which captures some key aspects of the practice of corporate governance in countries that place greater emphasis on relations as opposed to rules. In particular, we explain some important differences in the characteristics of the rules-based corporate governance model and the relations-based social system-i.e., how the latter is rooted in traditional cultural values and social codes that are commonly observed and carefully protected, but not expressed in legal rules and usually not fully explained to outsiders. The "fuzzy ownership" model is contrasted to other corporate governance forms prevalent in market economies (shareholder/finance-driven systems, team production/institutional systems and relational investor/main bank systems), and its cultural roots are contrasted to the economic and legal theories underpinning the other systems (rational actor/efficient market, behavioralist and patient capital theories). Section IV introduces our non-convergence proposition. In additional to the theoretical argument, we discuss some recent developments involving Korean companies that demonstrate corporate governance in Korea is unlikely to converge in any meaningful way toward a rules-based regime, due largely to a local preference for fuzzy ownership corporate governance and the relation-based social system. Concluding remarks, and the case for further study, are contained in Section V. 


\section{CONVERGENCE AND PERSISTENCE HYPOTHESES}

\section{Shareholder Primacy}

Many western-authored analyses of corporate governance take as their starting point the recognition of two sets of relevant participants: shareholder "owners" and manager "agents" who run the firm. Berle and Means founded this vision of the corporate form with their 1932 theory of the corporation based on "the traditional logic of property." 4 This property rights approach leads to a focus on the legal rules that govern shareholders' rights, and the law of agency relationships which create fiduciary duties for the agents (board of directors and executive management). The main inquiry, therefore, is stated narrowly as the principal-agent problem implicit in the separation of ownership from control at firms with widely dispersed shareholders. 5 Shareholders need protection from managers seeking private benefits (i.e., stealing) from the corporation; minority shareholders need additional protection from majority or controlling shareholders ${ }^{6}$ who have the opportunity, and have been found, to siphon off assets or profits from the firms they control, to the detriment of minority shareholders ("tunneling"). ${ }^{7}$ With shareholders identified as owner-principals, the ensuing evolution of corporate law and related regulatory structures has a singular objective function: protecting the property rights of shareholders. Other participants in the corporate enterprise (employees, customers, suppliers, creditors, government and other community bodies) play their roles as means to that end; the objective function of the corporation neglects to deal explicitly with their welfare.

\section{Convergence Predicted}

The current global discussion centers around the theory (or prediction) that the variety of different systems found in the market-based economies of the world will (and should) converge toward a uniform, shareholder-centered system, with financial and legal institutions that are necessary preconditions to healthy securities markets. ${ }^{8}$ Nations will choose to reform aspects of existing corporate governance schemes that do not match the expectations of the shareholder-oriented system, and will do so in order to support the development of deep, liquid equity markets and high listed-company valuations as investors reward them for good corporate governance. 9 The strong form of this argument is made by Hansmann and Kraakman:

Although there remained considerable room for variation in governance practices and in the fine structure of corporate law throughout the twentieth century, the pressures for further convergence are now rapidly growing $\cdots$ There is no 
longer any serious competitor to the view that corporate law should principally strive to increase long-term shareholder value. 10

In the convergence theory, the principal factors driving global consensus in favor of the shareholder primacy model are (i) the failure of experiments with alternative models, (ii) competitive pressures in global commerce and (iii) "the shift of interest group influence in favor of an emerging shareholder class." 11 This model requires that "shareholders alone are the parties to whom corporate managers should be accountable," and envisions "the abandonment of a privileged role for managers, employees, or the state in corporate affairs." 12 The logic of the shareholder-oriented model lies not in a preference for protection of shareholders over other interested parties in society, but rather in the proposition that the best and most effective means to the end (aggregate social welfare) is to make corporate managers "strongly accountable to shareholder interests, and (at least in direct terms) only to those interests." 13

Despite the logical appeal and probable efficiency of the shareholder-driven model, its connection to practical reality in the workings of companies in many parts of the world is somewhat tenuous, and the explanations it offers for corporate governance are incomplete. Observation of political, historical and financial matters suggests that there are significant barriers to global convergence.

\section{Politics Matters}

Other analyses have a wider scope, interpreting the firm as having three inputs: capital, management and labor. ${ }^{14}$ Corporate governance then involves a three-way balancing of power and allocation of corporate wealth. In social democracies, where labor plays a powerful role in national politics and corporate governance, employees have been described to effectively "own" their jobs pursuant to legal protections. ${ }^{15}$ Where labor institutions are strong and rigid, management and capital may evolve around labor institutions as a matter of necessity. In weakly competitive product markets, such as in small national economies with protected markets, rents exist in corporate firms (i.e., profits in excess of the required return on capital) and these rents are subject to political capture and social sharing, all of which gives rise to social democratic political structures. 16 Social democracies and protected product and labor markets are thus predicted to be complementary structures, supporting and reinforcing each other. This complementarity of institutions is the twin concept of "consistency" and presents a case for "friction" or "persistence" of elements in a given system that fit together well. A whole political and economic system is unlikely to change (or "converge") to another system, even if the other system is more efficient on the whole, due to switching costs which arise in real political settings as 
a consequence of "among other things, sunk costs, entrenched property, and decision rights of interest groups and network externalities." 17

\section{History Matters}

The unique features of firms, markets and legal institutions in any given nation were shaped by historical events, and modern differences in ownership structures and corporate governance institutions depend (at least partly) on their earlier patterns. ${ }^{18}$ Bebchuk and Roe conclude that this "path dependence" (identifying both ownership structures and legal rules, as influenced by interest-group politics, as sources of path dependence) helps explain why so many anomalous corporate structures have persisted around the world, even in the face of increasing globalization of product and capital markets. 19 Several explanations could account for persistence of a unique set of corporate institutions, including an equilibrium notion from evolutionary biology that a local optimum may be reached which is different from the global optimum (i.e, it may or may not be efficient, but may be sticky due to myopia beyond the "local hill") ${ }_{0}^{20}$

\section{Finance Matters}

Diverse ownership structures, sources of capital and political history have produced diverse corporate governance structures. If "finance determines governance," 21 then companies whose primary sources of capital are not equity will develop corporate governance systems with different characteristics based on their debt financing or government-sponsorship (for examples, the main bank systems in Germany and Japan and the largely state-owned economies). It follows that other diverse corporate governance systems will be at work where control rights over assets are politically or socially enforced, rather than legally enforced. 22 Legal rules may function differently or not at all, for example, in consensus-based Asian cultures which are built around tight social and family-based networks, and which display an aversion to resort to legal remedies, even where available.

While acknowledging a predictable array of barriers to adoption of the shareholder primacy model as the global norm, the proponents of convergence to a shareholder primacy model view the process as well underway and reflecting the "triumph of the shareholder-oriented model of the corporation over its principal competitors" in a competition among alternative corporate governance models during the post-WW II period. 23 In this view, the remaining task of law and policy is properly to align the interests of managers with shareholders (where control and ownership are separate) and to build shareholder-protective legal and regulatory structures to enable the development of public equity markets that are a precondition to the separation of ownership from control. 


\section{THE FUZZY OWNERSHIP RIGHTS MODEL}

We saw in the previous section that corporate governance systems evolve over time and vary from country to country. Instead of attempting to produce a detailed taxonomy of the corporate governance systems, for our purposes it will suffice to identify two main structures. The first model is the shareholder primacy, rules-based system which has its roots in the US and UK common law tradition. Let us call this the "SP model". The second model is what we will call the "fuzzy ownership system", commonly observed in economies where social relationships define the rights and responsibilities of market participants somewhat independent of legal rules. This "FO model" is defined by its cultural context and the types of firm behavior we describe hereafter. It shares some but not all characteristics with other non-SP forms, such as relational investing, main bank systems, team production theory and an "institutional view" of corporations, as explained below. It is uniquely characterized by a firm whose ultimate control is hidden, or where control is shared among or influenced by various constitutents other than, or in addition to, the majority of shareholders. The FO model firm more closely resembles a multi-stakeholder organization or social democracy than the SP model firm in its actual function; even where it is quite hierarchical in the internal command structure (as is the norm at Korean companies), individuals other than the major providers of capital hold as much sway with the company's decision-maker(s) as shareholders.

The main difference between the two models is easily demonstrated. Most importantly, there is the question of ownership. In the SP model, the ownership of the firm is exclusively in the hands of the stockholders who have provided equity capital. We will see that this has some far-reaching implications. On the other hand, in the FO model, the ownership of the firm rests not only with the stockholders, but also with some other stakeholders, such as debt-holders, employees, customers, suppliers, and government, who have contributed other relevant sources of capital (financial and non-financial). It should be noted that the concept of ownership is highly formalized in the SP model, so that only the ownership rights enshrined in law, regulation or contract are recognized or enforceable. In contrast, in the FO model the concept of ownership is much more informal. Ownership itself is often less important than duties owed to social or familial relations pursuant to the social code. Involvement in the corporate governance process by some corporate participants is socially recognized, effectively creating informal rights for the stakeholders and duties for the corporation. This informal mechanism works alongside the formal judicial system in the FO model.

The differing notions of ownership give rise to some important distinctions for corporate governance. SP model firms seek to maximize stock value. The FO model firm, however, has a complex optimization problem whose objective function goes beyond stock value maximization. FO firms exist to optimize 
a broad range of stakeholders' interests. Because the stakeholders often have conflicting interests (for example, the debt-holders will want the firm to pursue less risky projects, while the shareholders may prefer higher risk with higher expected returns), corporate governance carefully must weigh all the vested parties' interests. Here, good corporate governance means that the weights have been appropriately allocated.

The differing objective functions across the two models give rise to different corporate behaviors. FO model firms tend to have strategic or investment horizons that are longer than SP model firms. They also have a more intimate working relationship with the government and may be more eager to support actions and projects identified to be in the interest of the nation. In addition, they will yield to labor union or employee demands more readily. They may engage in inefficient empire-building as they expand beyond profitability, because the relative importance of total sales versus profits will be higher in FO model firms. As a corollary, the FO model will encourage the formation of conglomerates, cross-holding or chaebol (circular ownership) structures.

FO model firms share some attributes with companies in Japan and Germany for which a main bank is the primary supplier of capital and an informal regulator. However, the FO model firm is different in at least three identifiable respects: (1) a significant portion of its capital is supplied by shareholders through a public offering and the listing of shares on a stock exchange; (2) while a significant banking relationship also exists, the extent of control is weaker or muddled due to an overlay of additional duties to other "owners" in the FO model firm, and this weaker control is evidenced by the bank's lack of success in restraining the FO model firm from engaging in overly risky behavior; and (3) the banking relationship does not create a simple debtor-creditor relationship but is a tool of national industrial policy, meaning that the bank often does not act in its own best interest, but may be pressured by government and other social structures to help fulfill missions outside of the bank's profitability mission. Due to these differences of culture, development need and experience, the FO model firm is a less predictable actor. Its actions are the product of a more complex, less transparent set of interests than the bank-financed company.

The "relational investor" or "patient capital" solutions for corporate governance form one element of the FO model rationale: "if only more investors would take large positions and then carefully and patiently work with managers to maximize long-term value, corporations would thrive, takeovers would be unnecessary, and we would grow rich or at least richer." 24 However, the FO model does not stop at highly-valuing the long-term investor; it values similarly highly all its other long-term and mission-critical stakeholders (employees, regulators, supply chain partners and group affiliates). The FO model firm differs from the firm that seeks patient capital in that it seeks not only financial capital and other factors of production, but myriad other relationships which it also 
considers necessary to do business in its cultural context. There seems to be little or no hierarchy among the various factors and relationships based merely on traditional notions of shareholders as owners and others as non-owners, unlike the SP model firms for which relational investors are not an alternative to shareholder primacy but rather constitute a preferred type of shareholder.

The "team production theory of corporate governance" 25 looks to management and the board of directors as the keys to a successful corporate form, advocating control of a corporation at the board. In the team production firm, the directors serve as "mediating heirarchs," balancing the interests of all the firm's constituents, somewhat insulated from shareholder control. This places management in the power seat instead of shareholders, but does not necessarily involve the cultural context or opaque decision-making processes of the FO firm.

Similarly, an "institutional view" of the corporation 26 emphasizes management consistency and job security as pre-conditions for company success in the longer term. FO model firms naturally embrace team production and institutional concepts, in contrast to a "finance view" 27 of shareholders as ultimate and active decision-makers. However, FO model firms extend the institutional and team production models beyond the firm and its direct participants. FO model firms are as concerned with the cultural context of the firm in relation to its outsider affiliates, contractual relations, community and government as they are with the power struggle between shareholders and boards. Managers and controllers of FO model firms do not put on blinders when they make decisions for the company so as to consider narrowly the interests of the single entity. Rather, the interests of a wide and perhaps undefined (thus the "fuzzy" aspect) set of constituents drives decision-making at the highest levels.

If the nature of the participants in this decision calculus is known, we may find that decision-makers at FO model firm are the rational actors whose existence is assumed or hoped-for by SP model advocates. Does bomo economicus exist in FO model cultures, and is he susceptible of responding to good, carefully enforced corporate law? Perhaps, if the law and the institutional framework are a match with the cultural values motivating behavior at the $\mathrm{FO}$ model firm.

Clearly, the concept of fuzzy ownership is somewhat unsatisfactory from a scientific point of view. In the classic (western) theory of the firm, the objective is to maximize profit. Since only stockholders have a claim on profits, solving the profit maximization problem also solves the stock value maximization problem and similarly, the shareholder interest maximization problem. With fuzzy ownership, the firm is influenced by other parties beside the stockholders to solve a problem that goes beyond profit maximization. Exactly how the profit maximization problem changes will ultimately depend on the balance of power between the stakeholders with conflicting interests. For example, although Kookmin Bank was fully privatized many years ago, this bank still operates much like a state-owned bank, pursuing national interests at the cost of profit maximization. Other compa- 
nies have been used to support the personal ambitions of the founder or chairman, causing even this highly profitable companies to go bankrupt.

From a legal point of view, fuzzy ownership introduces some thorny questions. Consider the lawsuit that the creditors of Samsung Motor recently pressed against Samsung Group Chairman Lee Kun Hee and other Samsung Group companies. When Samsung Motor went bankrupt in 1998, it was not clear who would be responsible for repaying the creditors KRW 4.3 trillion of outstanding debt. After a great deal of public debate, the burden of debt repayment found its way to Mr. Lee Kun Hee and, buckling under social pressure, he agreed to take responsibility. At the time, he handed over his personal holdings of Samsung Life Insurance company shares, said to be worth KRW 2.8 trillion. For several years, the creditors tried unsuccessfully to sell this block of shares. They have since given up and instead are asking the court to force Mr. Lee Kun Hee and Samsung Group to compensate them for the unpaid debt and the interest that has accrued. At this point, it will be instructive to ask what Chairman Lee's ownership in Samsung Motor was. The answer: $0.03 \%$.

To the untrained eye, companies which operate in a fuzzy ownership environment often display strange corporate behavior. The strangeness stems from these firms' apparent disregard for stockholder interests and these actions are sometimes described as "irrational" or "corrupt". Without doubt, fuzzy ownership allows for a more liberal or subjective judgment in the selection of the objective function, producing an environment more amenable to corrupt behavior. This notwithstanding, a better understanding of fuzzy ownership, on the other hand, would suggest that corporate behavior that looked irrational under the stockholder value maximization paradigm is actually rational in the new FO paradigm.

Is fuzzy ownership good? This is a difficult question. Viewed theoretically, fuzzy ownership may force firms to solve optimization problems that go beyond stockholder maximization and in so doing add even greater social value. ${ }^{28}$ The FO firm may satisfy the need for social responsibility in corporate decision-making that is generally absent - and may be legally prohibited - for SP-model firms. Judgment may be complicated, however, and corporate governance becomes more art than science, in the FO environment. Can there be no rules as to whose FO interests prevail when those interests conflict? It is not completely inconceivable that in the future, with better incentive structures, the fuzzy ownership environment will possibly give rise to many great corporations. The track record to date, however, leaves much to be desired.

\section{NON-CONVERGENCE PROPOSITION}

Prior to the Asian financial crisis of 1997 , the region paid scant notice to the term "corporate governance." This does not mean that there was no corporate 
governance. Indeed, in the wake of the crisis, when blame had to be assigned, in the eyes of many analysts bad corporate governance earned the title of "main culprit." In an effort to correct this perceived weakness, Asian economies studied the practice of good corporate governance behavior in advanced equity markets (most notably the US and Britain) and attempted to initiate changes aimed at mimicking good behavior. ${ }^{29}$

The Korean experience is instructive. Corporate governance reform in Korea has focused largely on creating or improving formal protection of minority shareholders. 30 Prompted by activist shareholder demands and recommendations of international organizations, 31 the Korean government has enacted various measures that resemble legal standards from SP model nations. Interestingly, the targets of such regulations have in some cases openly embraced the reform effort. 32

How significant are these changes? And do these changes imply that the FO model is undergoing a transformation to the SP model in Korea?

It is still too early in the game to predict the final outcome with any degree of certainty. However, close scrutiny of theory and practice suggests that convergence, if achieved at all, will be at best superficial. We assume no change in the social and cultural context of a relation-based society, as it would require a revolution in fields other than corporate and securities law to alter the basis of social interaction from relationship networks to western-style individualism and rules-based values (and we refrain from speculating on the wisdom of such a cultural shift in addition to assuming it will not occur in any relevant term for corporate governance policy purposes).

From a theoretical point of view, true convergence is achieved only if two things take place. Step One: a FO model must be transformed into a SP model. Step Two: having shifted to a SP regime, the best practices from the SP regime are established. Clearly, going straight into Step Two, without having achieved Step One, will not bring about any meaningful changes. This is because formal creation of improved rights for minority equity owners may have limited impact in the FO model unless the other rights holders ratify the new shareholder rights. A consensus veto, or simple non-recognition, may be sufficient to nullify the formal rights.

In the FO model, beefing up the formal rights for one owner group does not necessarily diminish the rights vested in all the other corporate participants. Formal creation and informal adoption, then, of new shareholder rights fails as evidence of migration from the FO model to the SP model of corporate governance; it merely signals marginal changes within the FO model. Fuzzy ownership is not eliminated. It may be that the recent reform of shareholder (minority) rights has worked a distraction from the more helpful question for improving corporate governance - which is, how does this FO system actually work? Having incorrectly assumed, under the SP model paradigm, that the equity shareholder is the key to good governance, the heart of the problem 
remains unidentified.

Advocates of SP model good corporate governance will point to a series of institutional changes adopted by Korean companies as evidence of progress. However, the better test is to gauge the actual behavior. Consider first the case of SK Group. Soon after one of the worst corporate governance scandals in Korea in 2003, a self-styled corporate governance activist fund, Sovereign Asset Management, waged a battle for the management control of SK Corporation against the Chairman Chey Tae-won of the SK Group. Amazingly, Sovereign fought much of the battle with their opponent, Mr. Chey, in prison (charged and convicted of fraud related crimes) but were nevertheless defeated in a vote count at two General Shareholders' meetings. Evidently, despite his criminal past, the majority of the shareholders felt that Mr. Chey's continued leadership would be preferable to the alternative being proposed by Sovereign. That is to say, the SP proposition soundly failed the stress test.

The second case concerns Korea's premier chaebol group Samsung and their world-class company Samsung Electronics. Foreign ownership of Samsung Electronics has been above the $50 \%$ mark for several years. In comparison, the founding family and the Samsung Group companies combined hold only a $13.5 \%$ stake. From this simple observation, many Koreans anxiously fret about the possibility of a "foreign takeover" (and the relocation to another country) of Korea's most profitable company. The national angst has grown to such a fever pitch, the National Assembly lawmakers are considering ways to prevent a foreign hostile takeover of Samsung Electronics. It is worth noting that the key reason for considering any national action is the notion that Korea made Samsung Electronics and therefore owns it. This is the concept of fuzzy ownership at work at a macro level.

Examples of surface-thin cosmetic corporate governance changes abound in Korea. Moreover, the recent fraudulent accounting scandals at Turbo Tech and Locus, two blue chip names in Korean venture history, should serve as a warning that fuzzy rights play an important role in molding the behavior not only of older companies, but also those companies formed and nurtured in the aftermath of the financial crisis.

Those who support the convergence proposition might say that good corporate governance is not achieved overnight and that a country such as Korea, starting from a low base, obviously has a long way to go. Our theory suggests otherwise: as long as fuzzy ownership rights prevail, there can be no meaningful convergence.

\section{CONCLUSION}

Fuzzy rights concerning the ownership of corporations are a fact of life in many countries around the world. Some countries (Korea for example) will place 
considerable weight on fuzzy rights, while in other countries (the US for example) fuzzy ownership rights generally have not been recognized by the legal system. The existence of strong fuzzy ownership rights affects corporate governance in many important ways. In the presence of fuzzy rights, the firm is forced to go beyond solving the shareholder interest maximization problem. This is because in reality the firm must also attempt to maximize the interests of other fuzzy ownership right-holders as well.

The notion of different objective functions leading to different behaviors should not need much elaboration. In the wake of the Asian financial crisis, many countries in the region were encouraged to adopt western style corporate governance reforms. The importance of these reforms in strengthening minority shareholders' rights should not be overlooked. However, focusing solely on minority shareholders' rights oversimplifies the problem. In regimes with fuzzy ownership rights, firm behavior will not be greatly altered by systemic changes that leave the fuzzy ownership structure intact and only bestow greater rights to minority shareholders.

There is an off-hand chance that, over time, strengthening the rights of the minority shareholders will diminish fuzzy ownership rights. On the other hand, it should be noted that fuzzy rights holders rationally can be expected to protect their interests, and to refuse to surrender their rights if and when those rights are targeted by corporate reform efforts. The interests are personal to the holders because they arise from the holder's position in the economy or in relation to the firm and/or the individuals making decisions on behalf of the firm. Moreover, these interests generally are not transferable. Holding unmarketable rights, then, the corporate rights holders can be expected to remain vested, protecting their property interests and preserving the socio-economic environment that recognizes and supports those rights. These vested rights holders present a high barrier to convergence or migration of Korea's corporate governance system to a SP model.

Is corporate governance convergence desirable? Those advocating convergence commonly believe that the Anglo-Saxon shareholder primacy model will - or ought to - be the global standard to which all systems converge. If that is the case, then the crucial element that must be transformed is fuzzy ownership rights. To do this, the nature of fuzzy ownership rights must be carefully studied in their proper socio-economic, cultural and legal contexts.

\section{REFERENCES}

Allen, William T. and Leo E. Strine, Jr. 2005. When the Existing Economic Order Deserves a Champion: The Enduring Relevance of Martin Lipton's Vision of the Corporate Law. In The Business Lawyer, August.

Bebchuk, Lucian Arye and Mark J. Roe. 2004. A Theory of Path Dependence 
in Corporate Ownership and Governance. In Convergence and Persistence in Corporate Governance. eds. Jeffrey N. Gordon and Mark J. Roe. Cambridge: Cambridge University Press.

Berle, Adolf A. and Gardiner C. Means. 1932. The Modern Corporation and Private Property.

Black, Bernard S. 2001. The Legal and Institutional Preconditions for Strong Securities Markets. UCLA Law Review 8(781).

Black, Bernard S., Hasung Jang and Woochan Kim. 2005 (Forthcoming). Predicting Firms' Corporate Governance Choices: Evidence from Korea. Journal of Corporate Finance. http://ssm.com/abstract $=428662$.

Blair, Margaret M. and Lynn A. Stout. 1999. A Team Production Theory of Corporate Law. Virginia Law Review 85.

Bolgar, Catherine. 2005. Questions for the Future: Trust. The Wall St. Journal, November 2.

Hansmann, Henry and Reinier Kraakman. 2004. The End of History for Corporate Law. In Convergence and Persistence in Corporate Governance. eds. Jeffrey N. Gordon and Mark J. Roe. Cambridge: Cambridge University Press.

Johnson, Simon and Rafael La Porta, Florencio Lopez-de-Silanes and Andrei Shleifer. 2000. Tunnelling. Harvard Institute of Economic Research Discussion Paper Number 1998, January.

La Porta, Rafael, Florencio Lopez-de-Silanes and Andrei Shleifer. 1999. Corporate Ownership around the World. Journal of Finance 54(2): 471-517.

La Porta, Rafael and Florencio Lopez-de-Silanes, Andrei Shleifer and Robert Vishny. 1999. Investor Protection and Corporate Valuation. Harvard Institute of Economics Research Paper No. 1882. bttp://ssm.com/abstract $=192549$.

McCahery, Joseph A., Piet Moerland, Theo Raaijmakers and Luc Renneboog, eds. 2002. Corporate Governance Regimes: Convergence and Diversity. New York: Oxford University Press.

Milhaupt, Curtis J. 2004. Property Rights in Firms. In Convergence and Persistence in Corporate Governance. eds. Jeffrey N. Gordon and Mark J. Roe. Cambridge: Cambridge University Press.

OECD. 2004. Korea Report. Paris: OECD.

OECD. 2004. Principles of Corporate Governance. Paris: OECD. www.oecd.org/document $/ 49 / 0,2340, e n \_2649$ 37439_31530865_1_1_1_37439,00.html.

OECD. 2004. White Paper on Asian Corporate Governance. Paris: OECD.

Oman, Charles and Daniel Blum. 2005. Corporate Governance: A Development Challenge. OECD Policy Insights Issue No. 3, January.

Pak, Bliss Burdett. 2006. Global Precedent in Law and Policy to Promote Responsible Companies (Report to the Korea Securities Dealers Association, on file with the KSDA).

Rock, Edward B. 1994. Controlling the Dark Side of Relational Investing. Cardozo Law Review 15(987). 
Roe, Mark J. 2003. Political Determinants of Corporate Governance. Oxford: Oxford University Press.

Schmidt, Reinhard H. and Gerald Spindler. 2004. Path Dependence and Complementarity in Corporate Governance. In Convergence and Persistence in Corporate Governance. eds. Jeffrey N. Gordon and Mark J. Roe. Cambridge: Cambridge University Press.

Solomon, Jill, Aris Solomon and Chan-Young Park. 2002. A Conceptual Framework for Corporate Governance Reform in South Korea. Corporate Governance 10(1).

Tan, Gerald. 2000. The Asian Currency Crisis. Singapore: Times Academic Press.

\section{ENDNOTES}

1 See Gerald Tan. The Asian Currency Crisis (2000).

2 Indeed, as reported by The Joong Ang Daily amidst a debate about instituting class-action shareholder lawsuits in Korea, "tricky bookkeeping has been a long-established practice here. Indeed, even Shin Jong-ik, a senior official at the Federation of Korean Businesses, recently estimated that between half and 70 percent of Korean firms have been involved in accounting fraud." (The JoongAng Daily, June 6, 2003)

3 See Joseph A. McCahery, et al., eds. 2002. Corporate Governance Regimes: Convergence and Diversity. See also OECD. White Paper on Asian Corporate Governance (2004).

4 Adolf A. Berle \& Gardiner C. Means. 1932. The Modern Corporation and Private Property, at 333-39.

5 In the U.S., U.K. and other common law heritage countries where equity capital is a primary source of corporate finance, the widely dispersed owners of the classic Berle-Means corporation have greater legal protections as minority shareholders and the presence of a controlling shareholder is less common. See Rafael La Porta, Florencio Lopez-de-Silanes and Andrei Shleifer. April 1999. Corporate Ownership Around the World. The Joumal of Finance LIV(2) (hereinafter, "Corporate Ownership"). In other parts of Europe, South America and Asia, "controlling shareholders - usually the State or families - are present in most large companies."

${ }^{6}$ La Porta et al. conclude that the presence of a controlling shareholder suggests that most countries should "focus on the incentives and opportunities of controlling shareholders to both benefit and expropriate the minority shareholders." See Corporate Ownership, note 5. Others point to the need for effective enforcement of many good corporate governance laws now on the books.

${ }^{7}$ Simon Johnson, Rafael La Porta, Florencio Lopez-de-Silanes, Andrei Shleifer Tunnelling, Harvard Institute of Economic Research Discussion Paper (January 2000).

"High on the list of priorities for reform in many developing countries must be enhanced capacity to address the problem of insiders' abusive use of multiple share classes, cross-shareholding and pyramidal corporate control structures. In many countries it will required significantly greater public disclosure of effective share ownership, together with stronger measures to ensure the basic property rights of share ownership for domestic and foreign minority shareholders." Charles Oman and Daniel Blum, Corporate Governance: A Developing Challenge, in OECD Development Centre's Policy Insights No. 3.

${ }^{8}$ Bernard S. Black. 2001. The Legal and Institutional Preconditions for Strong Securities Markets. UCLA Law Review 8(781).

9 Evaluating "the influence on corporate valuation of investor protection and ownership data from 27 of the wealthiest economies around the world" and finding that "better shareholder protection is associated with higher valuation of corporate assets." Rafael La Porta, Florencio Lopez-de-Silanes, Andrei Shleifer and Robert Vishny, Investor Protection and Corporate Valuation, Harvard Institute of Economics Research Paper No. 1882 (October 1999), http://ssrn.com/abstract=192549.

${ }^{10}$ Henry Hansmann \& Reinier Kraakman. 2004. The End of History for Corporate Law. In Convergence and Persistence in Corporate Governance, at 33.

11 Id., at 36 .

${ }^{12} \mathrm{Id}$.

${ }^{13}$ The authors of the strong convergence hypothesis posit that "all thoughtful people believe that corporate enterprise should be organized and operated to serve the interests of society as a whole" - Id., at 43. 
${ }^{14}$ Roe defines, "the firm as having three inputs: capital, management, and labor," in Political Determinants of Corporate Governance, by Mark J. Roe (2003), at 112.

${ }_{16}^{15}$ Roe, Id., at 112 .

${ }_{17}^{16}$ Roe, Id., at 113 .

${ }^{17} \mathrm{ld}$., at 116 .

${ }^{18}$ Lucian A. Bebchuk and Mark J. Roe. 2004. A Theory of Path Dependence in Corporate Ownership and Governance. In Convergence and Persistence in Corporate Governance, at 69. ${ }^{19} \mathrm{Id}$.

20 "The main proposition here is that evolution leads stems - or collections of agents" striving for an improvement of their situation - only to local optima" - which may be different from the global optimum. "What constitutes the nearest, and seemingly most attractive, local optimum depends on the starting point at which a given biological or social system happens to be at a given point in time'.. "Modern evolutionary biologists use the metaphor of natural selection leading us to the tops of a local hill' [quoting Roe (1996)]" Reinhard H. Schmidt and Gerald Spindler. 2004. Path Dependence and Complementarity in Corporate Governance. In Convergence and Persistence in Corporate Governance, at 117.

${ }^{21} \mathrm{Id}$.

${ }^{22}$ Curtis J. Milhaupt. 2004. Property Rights in Firms. In Convergence and Persistence in Corporate Governance, at 211.

${ }^{23} \mathrm{Id}$.

${ }_{25}^{24}$ Edward B. Rock. 1994. Controlling the Dark Side of Relational Investing. Cardozo Law Review 15.

${ }^{25}$ Blair, Margaret M. and Lynn A. Stout. 1999. A Team Production Theory of Corporate Law. Virginia Law Review 85: 247.

${ }^{26}$ Allen, William T. and Leo E. Strine, Jr. 2005. When the Existing Economic Order Deserves a Champion: The Enduring Relevance of Martin Lipton's Vision of the Corporate Law. In The Business Lawyer, August 2005.

${ }_{28}^{27}$ Id.

${ }^{28}$ Certainly the corporate social responsibility movement is based on the logic that firms should and must rise above minimal legal requirements to fulfill their appropriate roles in society or even to maintain their right to operate in their current form. For reasons ranging from activist pressure to risk management to marketing, many companies in traditionally SP model jurisdictions have taken significant steps to join in the debate about corporate social responsibility and to report on their policies and activities in this area. See among others, www.csrwire.com, www.bsr.org and Bliss Burdett Pak, Global Precedent in Law and Policy to promote Responsible Companies. (Report to the Korea Securities Dealers Association, June 2006).

${ }^{29}$ Corporate governance is sometimes called "good corporate behavior". "Good" in terms of corporate behavior has been agreed among OECD member states to mean "fairness, transparency, accountability and responsibility" - principles which should govern the relationships between corporate management and shareholders. See the OECD, Principles of Corporate Governance (2004) (www.oecd.org/document $/ 49 / 0,2340$,en_2649_37439_31530865_1_1_1_37439,00.html).

${ }^{30}$ Jill Solomon, Aris Solomon and Chan-Young Park. January 2002. A Conceptual Framework for Corporate Governance Reform in South Korea. Corporate Governance 10(1): 34. See also Bernard S. Black, Hasung Jang and Woochan Kim. Predicting Firms' Corporate Governance Choices: Evidence from Korea. Journal of Corporate Finance, Forthcoming http://ssrn.com/abstract $=428662$; this study uses data from their KCGI index, based on responses to a 2001 survey of governance practices by the Korea Stock Exchange that includes 39 governance elements, divided into five categories: board structure, board procedure, disclosure and ownership parity.

${ }^{31}$ See OECD, Principles of Corporate Governance; OECD, White Paper on Asian Corporate Governance; and Oman and Blum, note 7 .

32 "Hyundai will embrace Western-standard governance structures and upgrade transparency..." Chung Mong-hun, Chairman of the Hyundai Group, quoted in Solomon, et al. (note 31), at 29. 